\title{
Prevalence of human papillomavirus infection in squamous cell carcinoma of the anal canal in a Northeast City in Brazil: viral genotyping and clinical aspects
}

Sulayne Janayna Araujo Guimarães ${ }^{1}$, Flávia Castello Branco Vidal ${ }^{1,2^{*}}$, Jéssica Maran Cavalcante Soares ${ }^{1}$, Maria do Desterro Soares Brandão Nascimento ${ }^{1,3}$, Luísa Lina Villa ${ }^{4}$ and Luciane Maria Oliveira Brito ${ }^{1,5}$

\begin{abstract}
Background: Anal cancer malignancies comprise about 1.5 to $3 \%$ of cancers from the gastrointestinal in which high-risk types of human papillomavirus (HR-HPV) is responsible for $>80 \%$ of cases. The aim of this work was to detect and perform human papillomavirus (HPV) genotyping in squamous cell carcinoma specimens from the anal canal and to investigate the association between viral infection and histopathological and clinical aspects.

Methods: The presence of genotype-specific HPV DNA in formalin-fixed paraffin embedded tissue from 27 anal SCC samples from a reference cancer hospital of São Luís, State of Maranhão, Brazil was performed by Linear Array HPV Genotyping Test and the INNO-LiPA HPV Genotyping Assay. Fisher's Exact test and Chi-square test were performed in order to evaluate the association between HPV type and clinical and morphological variables. $P$ values less than 0.05 were considered statistically significant.

Results: Average age of patients at the time of diagnosis was 54.96 years $\pm 15.81 ; 74.07 \%$ of patients were female. Vegetative ulcers represented the most common type of lesion (22.22\%). The lesions ranged in size from $2.1 \mathrm{~cm}$ to $5.0 \mathrm{~cm}$ and mostly were well-differentiated (70.38\%). Lymph node involvement was observed in $26 \%$ of the patients. Molecular evaluation revealed that HPV infection was detected in $81.48 \%$ of the lesions, and the most common type found was the oncogenic HPV 16. Statistical analysis indicated that the clinical and histopathological variables were not associated with HPV infection.
\end{abstract}

Conclusions: Our results indicate that anal SCC rarely occurs in the absence of HPV and emphasize the predominant role of HPV16. The evaluation about genotype-specific prevalence of HPV in anal SCC is important to assess the potential benefit of HPV vaccination.

Keywords: Anal cancer, Papillomavirus infections, Association, Molecular typing

\section{Background}

Squamous cell carcinoma (SCC) compromises more than $70 \%$ of all anal cancer malignancies, and represents 1.5 to $3 \%$ of cancers of the gastrointestinal tract $[1,2]$. Persistent infection with high-risk types of human papillomavirus (HR-HPV) is responsible for $>80 \%$ of cases.

\footnotetext{
* Correspondence: flavidal@hotmail.com

'Biobanco de Tumores e DNA do Maranhão, Universidade Federal do Maranhão, São Luís, Brazil

²Departamento de Morfologia, Universidade Federal do Maranhão, São Luís, Brazil

Full list of author information is available at the end of the article
}

SCC mainly affects women over the age of 50 years; among men, SCC predominantly affects individuals in the age range of 20 to 49 years [3]. There are few epidemiological data for anal human papillomavirus (HPV) infection in Brazil. According to Instituto Nacional de Câncer (INCA), in Brazil, anal cancer accounts for 1 to $2 \%$ of all colon tumors and 2 to $4 \%$ of all cancers that affect the large intestine [4]. This rate rises to alarming proportions in specific risk groups, such as in homosexual men and in HIV-positive patients. Palesfky et al. [5] reported that the incidence of anal HPV was 61 and $93 \%$ 
in HIV-seronegative and HIV-seropositive homosexual male patients, respectively. In women, the corresponding values were 42 and $76 \%$, respectively.

Although HPV infection is essential for the development of anal SCC, the exact frequency of this disease is not known. In Brazil, the data regarding this type of cancer are included in the statistics for colorectal cancer. Therefore, epidemiological data representative of a specific region is essential for implementing particular guidelines for treatment and prevention, e.g. an effective vaccination schedule, especially in high-risk groups. HPV infection, a sexually transmitted disease (STD) with potentially malignant development, that affects both men and women, is of global concern. There is a lack of studies about anal cancer in the Northeast region of Brazil, where social-economic conditions are precarious. Therefore, a thorough study of the prevalence and genotyping of HPV in patients diagnosed with anal cancer in São Luís, a city of the Northeast region, is potentially important for the prevention and early diagnosis of this disease. In addition, the understanding of HPV prevalence and knowledge of the viral subtype distribution constitute important epidemiological information that can assist the development of local or regional public policies to prevent HPV and of new vaccines.

The aims of this study were to detect and assess genotype-specific HPV prevalence in patients with anal SCC and to examine the association between viral presence and clinicopathological aspects of disease.

\section{Methods}

\section{Enrollment}

Retrospective study performed in paraffin-embedded anal tumor tissue samples collected from two public reference hospitals in Maranhão, a city in the Northeast region of Brazil. The 27 samples included in the study were from patients diagnosed with anal cancer between the years of 2001 and 2011. Patient information and data on histopathological characteristics of tumors were obtained from medical records. As the samples were obtained from paraffin-embedded tumors, written informed consent was not required from the patients. The identity of the patients was not disclosed in this study. This work was approved by the Ethics in Research Committee of the University Hospital of the Federal University of Maranhão (n 348.397).

Inclusion criteria:

Paraffin blocks and histological slides of anal tumors as a result of biopsy or surgical treatment at any followup in the archives of the Pathology Services. Exclusion criteria: Patients in which reports did not provide complete information.

\section{HPV detection}

The histopathological characteristics of the samples were reviewed by the pathologist, and blocks with tumor representativeness (over 50\% of the total area of the fragment) were selected. After microtomy, the sections were deparaffinized and stored at $4^{\circ} \mathrm{C}$ for DNA extraction. The extraction of genomic DNA from the samples was performed using the QIAamp DNA FFPE Tissue Purification Kit (QIAGEN ${ }^{\circ}$ ) according to the extraction protocol suggested by the manufacturer.

The amplification and HPV genotyping was performed using the INNO-LiPA HPV Genotyping Extra kit (INNOGENETICS), which is capable of detecting 28 different HR types of $\operatorname{HPV}(16,18,26,31,33,35,39,45$, $51,52,53,56,58,59,66,68,73$, and 82$)$, a number of low-risk HPV genotypes $(6,11,40,43,44,54$,and 70$)$, and the additional types 69,71 , and 74 . Hybridized band signals corresponding to HPV types were visually interpreted according to the manufacturer's instructions.

\section{Statistical analysis}

The data was tabulated using the Microsoft Office ${ }^{\circ}$ Excel 2010 application for calculation of frequencies, mean, median, standard deviation, minimum, and maximum of the variables used in the EpiInfo 7 program. The descriptive statistics for categorical variables were represented as a distribution of frequencies. Means, medians, standard deviation, minimum, and maximum values, and confidence intervals were used to represent numerical variables. Tables and graphs were constructed following the descriptive analysis. In order to evaluate the relationship between epidemiological and clinical data and the presence of HPV, the chi-square

Table 1 Age and clinical presentation of 27 patients diagnosed with anal cancer

\begin{tabular}{lll}
\hline & $N=27$ & Percent \\
\hline Sex & 20 & 74.07 \\
Female & 07 & 25.93 \\
Male & & \\
Age at diagnosis & $54.96 \pm 15.81$ & \\
Mean age & 04 & 14.81 \\
$\leq 42$ & 11 & 40.75 \\
$42-52$ & 06 & 22.22 \\
$53-63$ & 02 & 7.41 \\
$64-74$ & 04 & 14.81 \\
$75-86$ & & \\
Lesion area & 03 & 11.11 \\
Anal edge & 19 & 70.37 \\
Anal canal & 05 & 18.52 \\
Anal edge and canal &
\end{tabular}


Table 2 Pathologic characteristics of anal tumors from 27 patients diagnosed with anal cancer

\begin{tabular}{|c|c|}
\hline Predominant morphology & \\
\hline Ulceration & \\
\hline Vegetating & \\
\hline Ulceration and vegetating & \\
\hline Stenosing & \\
\hline Non evaluated & \\
\hline Size of the lesion (cm) & \\
\hline$\leq 0,5$ & \\
\hline $0.6-2.0$ & \\
\hline $2.1-5.0$ & \\
\hline$\geq 5.1$ & \\
\hline UJCC/TNM Staging & \\
\hline । & \\
\hline$\|$ & \\
\hline III & \\
\hline IV & \\
\hline Non evaluated & \\
\hline Tumor Grade & \\
\hline Well Differentiated & \\
\hline Moderately Differentiated & \\
\hline Poorly Differentiated & \\
\hline Undifferentiated & \\
\hline Invasion & \\
\hline Present & \\
\hline Absent & \\
\hline Not evaluated & \\
\hline Infiltration & \\
\hline Anal canal wall & \\
\hline Perianal region & \\
\hline Perirectal fat & \\
\hline Vagina and uterine cervix & \\
\hline Stroma & \\
\hline Muscle layer & \\
\hline Perineural & \\
\hline Vulvar & \\
\hline Not evaluated & \\
\hline No infiltration & \\
\hline Lymph node involvement & \\
\hline Yes & \\
\hline No & \\
\hline Not evaluated & \\
\hline Metastasis & \\
\hline Yes & \\
\hline No & \\
\hline
\end{tabular}

7.41

33.33

0

51.85

22.22

70.38

3.7

Table 2 Pathologic characteristics of anal tumors from 27 patients diagnosed with anal cancer (Continued)

\begin{tabular}{lcc}
\hline Not evaluated & 05 & 18.52 \\
Inflammatory process & & \\
Yes & 05 & 18.52 \\
No & 12 & 44.44 \\
Not evaluated & 10 & 37.04 \\
Necrosis Presence & & \\
Yes & 02 & 7.41 \\
No & 12 & 44.44 \\
Not evaluated & 13 & 48.15 \\
\hline
\end{tabular}

test and Fisher's exact test were used, and the results were considered statistically significant at $5 \%$ probability and for $p<0.05$.

\section{Results}

Anal tumor biopsies were evaluated in 27 patients aged $32-85$ years, with a mean age of 54.96 years and standard deviation of \pm 15.81 , presenting a higher prevalence between 42 and 52 years (Table 1). Among the patients involved in the study, $74.07 \%(20 / 27)$ were female. The demographic and distribution of clinical is shown on Table 1.

With regard to the location of the lesions, the anal canal was the most affected area. Vegetating and ulcerative lesions, observed in $22.22 \%$ of the cases, were the most commonly occurring type of lesion. Most lesions (55.56\%) were between 2.1 and $5.0 \mathrm{~cm}$ in size.

Table 2 demonstrate the pathological characteristics of the anal tumors analyzed. According to UJCC/TNM staging, most tumors were grade III (33.33\%) and moderately differentiated (70.38\%). The findings indicate that invasion was present in $33.33 \%$ of the tumors examined, and that infiltration occurred in at least one of the structures (anal canal wall, perianal region, perirectal fat, vagina and uterine cervix, stroma, muscle layer, perineural and vulvar). Lymph node involvement was found in $25.93 \%$ of the tumors examined.

HPV DNA was detected in $81.48 \%(22 / 27)$ of the anal tumor samples. All tumors (100\%) were found to be infected with high-risk viral types; HPV-16 was present in all samples (Fig. 1). Among the high-risk HPV types, types $18,29,39,45,52,59,66$, and 68 were also present. HPV-11 was the only low-risk genotype detected. In addition, in $50.09 \%(12 / 22)$ of the samples, only one viral type (simple infection) was detected. HPV-16 infection, which is associated with high oncogenic risk, was found in all cases studied. The prevalence of multiple infections in the samples studied was $45.45 \%(10 / 22)$ (Table 3$)$. 


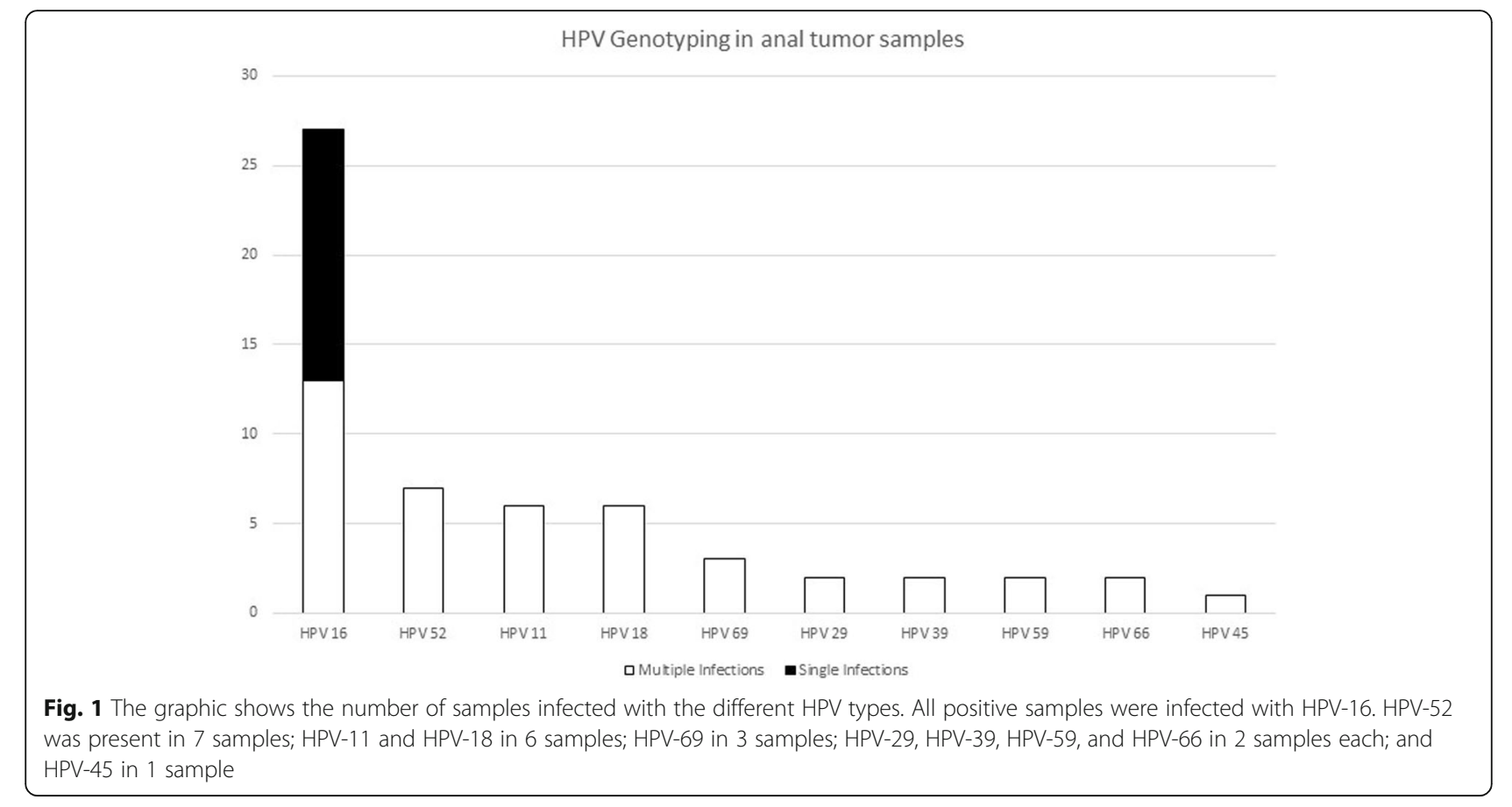

No association was found $(p<0.05)$ between HPV infection and histopathological and clinical variables (Table 4).

\section{Discussion}

The results of the present study indicate that most patients with anal SCC was 54.96 years constituting a sample younger than that reported in the literature. According to several researches, the peak incidence of anal cancer is between the ages of 58 and 64 years [6-10]. The mean age of patients with anal cancer may had vary among studies, possibly because of the type of population studied and the presence of risk factors such as sexual orientation, immunosuppression (patients with HIV+ infection and transplant recipients), tobacco smoking, and alcoholism [6-10].

We did not evaluated the social economic status of our population but the study was developed on a very poor area of Brazil, with one of the lowest human development indexes. According to National Cancer

Table 3 HPV prevalence and distribution according to oncogenic risk in 27 patients diagnosed with anal cancer

\begin{tabular}{lll}
\hline & $N=27$ & Percent \\
\hline HPV - & 5 & 18.52 \\
HPV + & 22 & 81.48 \\
$\quad$ HR-HPV & & \\
$\quad$ LR-HPV & & \\
Single infection & 12 & 50.09 \\
Multiple infections & 10 & 45.45 \\
\hline
\end{tabular}

Institute, cervical cancer and penile cancer are the second more incident type of cancer among women and men, respectively, in Maranhão [4]. Both cancer, as well as anal SCC, are associated with HPV infection and with poor social-economic status, health conditions and hygiene practices of the population. This condition may explain the younger status of our studied population.

Our samples presented a high prevalence of HPV, which are consistent with those reported in the literature. Alemany and coauthors applied a retrospective approach (1986-2011) to evaluate 496 cases of invasive anal cancer for DNA-HPV presence in a multi-center study involving patients from Europe, North America, Latin America, Africa, and Asia. The prevalence of HPV infection for each continent was 87.6, 95.8, 90.4, 61.9, and $81.1 \%$, respectively [10]. In Brazil, Aguiar and coauthors conducted a study of patients with anal carcinomas in Goiânia-Goiás, and found that $76.3 \%$ of the samples collected were positive for HPV [9]. The results of our study also corroborate the findings of Varnai and colleagues [11], Ramamoorthy and colleagues [12], de Vuyst and colleagues [13], and Rodel and colleagues [14], who reported the detection of HPV-DNA presence in $60.6,80,73$, and $95.8 \%$ of anal cancer samples examined, respectively.

Torres Neto and colleagues [15] performed a retrospective study about mains demographics characteristics of anal cancer patients in Sergipe, another city of Northeast State of Brazil. However, they did not performed any HPV analysis. 
Table 4 Association between clinical presentation and pathological characteristics in HPV infected patients with anal cancer

\begin{tabular}{|c|c|c|c|}
\hline & $\mathrm{HPV}(+) N=22$ & $\mathrm{HPV}(-) N=5$ & $p$ \\
\hline Gender & & & $0.1751^{\mathrm{a}}$ \\
\hline Female & 17 & 3 & \\
\hline Male & 05 & 2 & \\
\hline Site of primary tumor & & & $0.2386^{\mathrm{a}}$ \\
\hline Anal Margin & 3 & - & \\
\hline Anal Canal & 15 & 5 & \\
\hline Anal Margin and Canal & 3 & 3 & \\
\hline Lesion type & & & $0.7809^{a}$ \\
\hline Ulceration & 3 & 1 & \\
\hline Vegetating & 2 & - & \\
\hline Ulceration and Vegetating & 5 & 1 & \\
\hline Stenosing & 1 & - & \\
\hline Non evaluated & 10 & 06 & \\
\hline Size of the lesion $(\mathrm{cm})$ & & & $0.3657^{a}$ \\
\hline$\leq 0.5$ & - & 1 & \\
\hline $0.6-2.0$ & 6 & 2 & \\
\hline $2.1-5.0$ & 11 & 4 & \\
\hline$\geq 5.1$ & 03 & - & \\
\hline UJCC/TNM Staging & & & $0.7542^{a}$ \\
\hline । & - & 1 & \\
\hline$\|$ & 2 & - & \\
\hline III & 9 & - & \\
\hline IV & - & - & \\
\hline Non evaluated & 9 & 6 & \\
\hline Lymph node involvement & & & $0.3133^{*}$ \\
\hline Yes & 7 & - & \\
\hline No & 11 & 5 & \\
\hline Non evaluated & 2 & 2 & \\
\hline Inflammatory process & & & $0.3017^{\mathrm{a}}$ \\
\hline Yes & 3 & 2 & \\
\hline No & 12 & 2 & \\
\hline Non evaluated & 6 & 4 & \\
\hline
\end{tabular}

Significant $p$ values $<0.05$

a Fisher's test

* Chi-square

Infection with oncogenic, or high-risk, HPV-16 was detected in all cases. Other studies also report that HPV-16 was the main HPV type found in over $80 \%$ of carcinomas [10, 16-18].

Female patients constituted the majority of the cases on our work. Alemany and co-authors [10] found that female patients constituted the majority of the cases of SCC (66.3\%). Ouhoummanea and co-authors [8] found that the majority of incidence of anal cancer (60\%) was in women. Aguiar and colleagues found that $62.8 \%$ of patients with anal cancer were women [9]. The results of a study of Czech patients with anal cancer by Tachezy et al. [6], in which the same number of patients was analyzed as in our study, revealed that $52.4 \%$ of the patients were female. Two other studies, conducted in Brazil, found that the occurrence of anal cancer was 62.8$78.8 \%$ among the female patients studied $[19,20]$.

The prevalence of anal SCC in women may be explained by the anatomical proximity between the vaginal opening and the anus. A study by Giraldo and coauthors [21] of 184 Brazilian women demonstrated a significant association between cervical intraepithelial lesions and anal intraepithelial lesions. Anal lesions were found to be present in $17.4 \%$ of patients with genital lesions, but only in $3.2 \%$ of patients without genital lesions. HPV infection in women may also be facilitated by non-sexual practices and self-inoculation (via vaginal secretions, transfer of fomites, and digital transfer), in view of the anatomical proximity between the vaginal opening and the anus $[11,22]$.

In what concerns the pathologic characteristics of the anal SCC samples, the most common morphology type observed on our work was the ulcerative form, presented a size of $2.1-5.0 \mathrm{~cm}$, came from the anal canal region and moderately differentiated. However, the majority did not present invasion, infiltration, metastasis, and lymph node involvement. These clinical pathological characteristics are in accordance with others findings. Salati and Kadi [23] reported that the mean size of anal tumors investigated in their study was $3.9 \mathrm{~cm}$. They report that spread of anal cancer is mainly local and regional. Usually, the tumor spreads into the ischiorectal fossae, the prostatic urethra and bladder in men, and the vagina in women. Anal cancer may spread via the lymphatic vessels (10-15\%). Hematogenous spread develops in fewer than $10 \%$ of cases [23]. Studies have shown that the incidence of nodal metastasis in anal cancer is low (approximately 10\%) [17, 24]. Ouhoummanea and co-authors [8] reported that, of the tumors studied, $43 \%$ were moderately differentiated.

No statistically significant association $(p<0.05)$ was found between HPV infection and clinical and histopathological variables. Other reports have also concluded that anal tumors are highly likely to be positive for infection with HR-HPV, regardless of the morphology of the tumor [6].

The understanding of HPV prevalence and knowledge of the viral subtype distribution constitute important epidemiological information that can assist the development of local or regional public policies to prevent HPV and of new vaccines. The present study, in agreement with other epidemiological and molecular studies, demonstrates that HPV infection is an important etiological agent of anogenital cancer [21, 25]. 


\section{Conclusion}

HPV DNA was found in 22 of the 27 analyzed samples (81.48\%). The high-risk type HPV 16 was observed in $100 \%$ of the lesions while HPV-11 was the only low-risk genotype detected. The average age of the patients in the study was 54.96 years old. Prevalent lesions were larger than $2 \mathrm{~cm}$, grade III $(33.33 \%)$ and moderately differentiated $(70.38 \%)$. The clinical and histopathological variables did not tend to have an association with infection by the HPV virus.

\section{Abbreviations \\ HPV: Human papillomavirus; HR-HPV: High-risk human papillomavirus; SCC: Squamous cell carcinoma; STD: Sexually transmitted disease}

\section{Acknowledgements}

Not applicable.

\section{Funding}

This work was supported by Fundação de Amparo à Pesquisa e Desenvolvimento Científico do Maranhão (FAPEMA) grant number: APPUNIVERSAL-00508/12.

\section{Availability of data and materials}

The datasets used and/or analyzed during the current study available from the corresponding author on reasonable request.

\section{Authors' contributions}

SJAG, FCBV and JMCS performed DNA extraction, viral analysis and patient data collection. Viral genotyping was performed under the supervision of LLV. FCBV, MDSBN and LMOB analyzed and interpreted the data. SJAG wrote the manuscript draft, which was read and edited by all the authors. All authors read and approved the final version of the manuscript.

\section{Competing interests}

The authors declare that they have no competing interests.

\section{Consent for publication}

Not applicable. According to Resolução 466 CNS, item "IV.8 - Nos casos em que seja inviável a obtenção do Termo de Consentimento Livre e Esclarecido ou que esta obtenção signifique riscos substanciais à privacidade e confidencialidade dos dados do participante ou aos vínculos de confiança entre pesquisador e pesquisado, a dispensa do TCLE deve ser justificadamente solicitada pelo pesquisador responsável ao Sistema CEP/CONEP, para apreciação, sem prejuízo do posterior processo de esclarecimento".

\section{Ethics approval and consent to participate}

This work was approved by the Ethics in Research Committee of the University Hospital of the Federal University of Maranhão ( $n^{\circ}$ 348.397)

\section{Publisher's Note}

Springer Nature remains neutral with regard to jurisdictional claims in published maps and institutional affiliations.

\footnotetext{
Author details

'Biobanco de Tumores e DNA do Maranhão, Universidade Federal do Maranhão, São Luís, Brazil. ²Departamento de Morfologia, Universidade Federal do Maranhão, São Luís, Brazil. ${ }^{3}$ Departamento de Patologia, Universidade Federal do Maranhão, São Luís, Brazil. ${ }^{4}$ Departamento de Oncologia e Radiologia, Universidade de São Paulo, São Paulo, Brazil. ${ }^{5}$ Departamento de Medicina II, Universidade Federal do Maranhão, São Luís, Brazil.
}

Received: 28 November 2016 Accepted: 5 May 2017

Published online: 06 June 2017

\section{References}

1. Jemal A, Siegel R, Ward E, Hao Y, Xu J, Thun MJ. Cancer statistics, 2009. Cancer J Clin. 2009:59(4):225-49.

2. Grulich AE, Poynten IM, Machalek DA, Jin F, Templeton DJ, Hillman RJ. The epidemiology of anal cancer. Sex Health. 2012;9(6):504-8.

3. Palefsky JM, Rubin M. The epidemiology of anal human papillomavirus and related neoplasia. Obstet Gynecol Clin North Am. 2009;36:187-200.

4. INSTITUTO NACIONAL DO CÂNCER (INCA). Estimativa 2016. Rio de Janeiro: Incidência de Câncer no Brasil; 2015.

5. Palefsky JM, Holly EA, Ralston ML, Costa M, Greenblatt RM. Prevalence and risk factor for anal human papillomavirus infection in human immunodeficiency virus HIV-positive and high-risk HIV-negative women. J Infect Dis. 2001;183:383-91.

6. Tachezy R, Jirasek T, Salakova M, Ludvikova V, Kubecova M, Horak L, et al. Human papillomavirus infection and tumours of the anal canal: correlation of histology, PCR detection in paraffin sections and serology. APMIS. 2007; 115(3):195-203.

7. Abramowitz L, Jacquard AC, Jaroud F, Haesebaert J, Siproudhis L, Pradat P, et al. Human papillomavirus genotype distribution in anal cancer in France: the EDiTH V study. Int J Cancer. 2011;129:433-9.

8. Ouhoummanea $N$, Steben $M$, Coutlee F, Vuong T, Forest P, Rodier C, et al. Squamous anal cancer: Patient characteristics and HPV type distribution. Cancer Epidemiol. 2013:37:807-12.

9. Aguiar MTM, Bosso NCC, Leal CBQS, Lira CF, Cabral LAO, Silva AMTC, et al. Clinicopathological aspects and prevalence of human papillomavirus in anal cancer. J Coloproctol. 2014;34(2):76-82.

10. Alemany L, Saunier M, Alvarado-cabrero I, Quiros B, et al. Human papillomavirus DNA prevalence and type distribution in anal carcinomas worldwide. Int J Cancer. 2015;136(1):98-107.

11. Varnai $A D$, Bollmann $M$, Griefingholt $H$, Speich N, Schmitt C, Bollmann $R$, et al. HPV in anal squamous cell carcinoma and anal intraepithelial neoplasia (AIN). Impact of HPV analysis of anal lesions on diagnosis and prognosis. Int J Colorectal Dis. 2006;21:135-42.

12. Ramamoorthy S, Liu YT, Luo L, Miyai K, Lu Q, Carethers JM, et al. Detection of multiple human papillomavirus genotypes in anal carcinoma. Infect Agents Cancer. 2010;5:17.

13. de Vuyst H, Clifford GM, Nascimento MC, Madeleine MM, Franceschi S Prevalence and type distribution of human papillomavirus in carcinoma and intraepithelial neoplasia of the vulva, vagina and anus: a meta-analysis. Int J Cancer. 2009;124(7):1626-36

14. Rodel F, Wieland U, Fraunholz I, Kitz J, Rave-Fränk M, Wolff HA, et al. Human papillomavirus DNA load and p16INK4a expression predict for local control in patients with anal squamous cell carcinoma treated with chemoradiotherapy. Int J Cancer. 2015;136(2):278-88.

15. Torres Neto JR, Prudente ACL, Santos RL. Estudo demográfico do câncer de canal anal e ânus no estado de Sergipe. Rer Bras Coloproct. 2007;27(2): $190-5$.

16. Kagawa R, Yamaguchi T, Furuta R. Histological features of human papilloma virus 16 and its association with the development and progression of anal squamous cell carcinoma. Surg Today. 2006;36:885-91.

17. Laytragoon-Lewin N, Nilsson PJ, Castro J, Gharizadeh B, Nyren P, Glimelius B et al. Human papillomavirus (HPV), DNA aberrations and cell cycle progression in anal squamous cell carcinoma patients. Anticancer Res. 2007; 27(6C):4473-9.

18. Komloš KF, Kocjan BJ, Košorok P, Rus T, Toplak J, Bunič M, et al. Distribution of HPV genotypes in Slovenian patients with anal carcinoma: preliminary results. Dermato Venerol Alp Pannonica Adriat. 2011;20(3):141-3.

19. Silva ITC, Araújo JR, Andrade RV, Cabral CR, Gimenez FS, Guimarães AG, et al. Anal cancer precursor lesions in HIV-positive and HIV-negative patients seen at a tertiary health institution in Brazil. Acta Cir Bras. 2011:26(1):64-71.

20. Soares PC, Ferreira S, Villa LL, Matos D. Identification of human papillomavirus in patients with anal squamous cell carcinoma and its relation with the grade of cellular differentiation and staging. Rev Bras Coloproct. 2011;31(1):8-16

21. Giraldo P, Jacyntho C, Costa C, Iglesias M, Gondim C, Carvalho F, et al. Prevalence of anal squamous intra-epithelial lesion in women presenting genital squamous intra-epithelial lesion. Eur J Obstet Gynecol Reprod Biol. 2009;142(1):735 
22. Yu T, Ferber MJ, Cheung TH, Chung TK, Wong YF, Smith DI. The role of viral integration in the development of cervical cancer. Cancer Genet Cytogenet. 2005;158(1):27-34.

23. Salati SA, Al Kadi A. Anal cancer - a review. Int J Health Sci (Qassim). 2012; 6(2):206-30.

24. Roldán Urgoiti GB, Gustafson K, Klimowicz AC, Petrillo SK, Magliocco AM, Doll CM. The prognostic value of HPV status and p16 expression in patients with carcinoma of the anal canal. PLoS One. 2014;9(10):e108790.

25. Gami B, Kubba F, Ziprin P. Human papilloma virus and squamous cell carcinoma of the anus. Clin Med Insights Oncol. 2014;8:113-9.

Submit your next manuscript to BioMed Central and we will help you at every step:

- We accept pre-submission inquiries

- Our selector tool helps you to find the most relevant journal

- We provide round the clock customer support

- Convenient online submission

- Thorough peer review

- Inclusion in PubMed and all major indexing services

- Maximum visibility for your research

Submit your manuscript at www.biomedcentral.com/submit
Biomed Central 